\title{
Changing Pattern of Plasma Cortisol \\ Level Associated with Feeding in Sheep
}

\author{
Shinji Murayama, Kazuyuki Moriya* \\ and Yoshiyuki SASAKI \\ Department of Animal Science, College of Agriculture, \\ Kyoto University, Kyoto-shi 606
}

(Received September 12, 1984)

\begin{abstract}
To examine the contribution of feeding to circadian variations in the plasma cortisol level in sheep, we observed the changes in the plasma cortisol level at 15-minute intervals for 12 hours (0800-1945) in 4 sheep accustomed to a regular schedule of feeding at 1000 and 1800 . The trial was repeated three times at one-week intervals. Data were analysed by the method of least squares analysis of variance, where the time grouped in every 2-hour period was adopted as a source of variation. The plasma cortisol level was significantly affected by the time $(\mathrm{P}<0.01)$. A significant rise in least squares means of the plasma hormone level was observed during the 2 -hour period prior to feeding in the morning $(P<0.01)$. Decreases of the hormone level were also observed after feeding both in the morning and in the evening $(\mathrm{P}<0.01)$. Thus, a changing pattern in the plasma cortisol level associated with feeding was shown in sheep, as already established in rats.

Jpn. J. Zootech. Sci., 57 (4): 317-323, 1986

Key words: sheep, cortisol, feeding
\end{abstract}

In many mammalian species, circadian variations in the plasma glucocorticoid levels have been observed. The changes seem to be colsely related to the animal's daily cycle of activity. The peak in the plasma glucocorticoid level occurs just before their most active period. It can be postulated that the roles of the circadian rise may be to activate various enzymes prior to the expected increase in the animals' activities including feeding ${ }^{1)}$ and to synchronize various autonomously fluctuating biological functions ${ }^{2.3)}$.

In rats, a close relationship between circadian variations in the plasma corticostrone level and feeding has been demonstrated ${ }^{4-8}$. That is to say, the circadian peak in the plasma corticostrone level occurred naturally during the transition period from day to night when they began to be active. When rats were accustomed to regularly scheduled feeding, the time of the peak of the hormone level was shifted to the time just before feeding. It is, therefore, theorized that circadian variation in the plasma corticosterone level can be synchronized by the daily feeding cycle in rats.

In sheep, the occurrence of circadian variations in the plasma cortisol level has been shown by many investigators ${ }^{7-13}$, but the pattern has not been well established yet. There is a considerable inconsistency in these reports. Differences in experimental conditions, particularly in feeding conditions, have probably contributed to this

\footnotetext{
* Present address: Department of Animal Science, Miyazaki University, Mayazaki-shi 880
} 
inconsistency, Our present study was conducted to determine the effect of feeding on the plasma level of cortisol in sheep.

\section{Materials and Methods}

\section{Animals}

Four adult Japanese Corriedale wethers, weighing $40.2 \pm 6.6 \mathrm{~kg}$ (Mean \pm S. D.) were placed in cages individually under natural daylight condition. They were fed twice daily at 1000 and 1800 with a maintenance ration, consisting of ground barley and alfalfa-meal $(5: 1)$ as concentrate and chopped orchard hay as roughage. Water was offered ad libitum. They had been accustomed to these conditions for three weeks before the first sampling day.

\section{Plasma sampling}

One $\mathrm{m} l$ blood samples were collected at 15 -minute intervals from 0800 to 1945 via an indwelling jugular cannula inserted the day before. This sampling procedure was repeated for three times at one-week intervals, i. e., on $5 / 19,5 / 27$ and $6 / 2$ in 1981 as Repeat 1, 2 and 3, respectively. On the day of sampling, animals were fed and watered as usual. To accustom the animals to the sampling procedure, a preliminary sampling was done at one week before Repeat 1 by the same procedure. Plasma was separated by centrifugation at $4^{\circ} \mathrm{C}$ and stored at $-20^{\circ} \mathrm{C}$ until assay.

\section{Radioimmunoassay}

Plasma cortisol concentration was measured using the method described by MakINo and KaMBEGAWA ${ }^{14}$. Plasma samples $(0.05-0.1 \mathrm{ml})$ mixed with water amounting to $0.3 \mathrm{~m} l$ were extracted with $3 \mathrm{~m} l$ of methylene chloride. One $\mathrm{m} l$ of the extract was dried. The residue was dissolved in $0.1 \mathrm{ml}$ of benzene-methanol solvent $(85: 15 \mathrm{v} / \mathrm{v})$ and was loaded on a microcolumn packed with Sephadex LH-20 (Pharmacia Fine Chemicals, Uppsala, Sweden) and eluted with the same benzene-methanol solvent. A portion of effluent from $2.2 \mathrm{ml}$ to $4.0 \mathrm{ml}$ was collected as a cortisol fraction. This portion was dried, and mixed with $0.2 \mathrm{ml}$ of diluted antiserum (1/8000) and $0.2 \mathrm{ml}$ of $1,2^{-{ }^{8}} \mathrm{H}$-cortisol $(53.3 \mathrm{Ci} / \mathrm{mmol}$, New England Nuclear, Boston, Massachusetts, USA) dissolved in borate buffer consisting of $0.05 \mathrm{M}$ boric acid, $0.05 \mathrm{M}$ potassium chloride, $0.05 \mathrm{M}$ sodium hydroxide, $0.06 \% \mathrm{BSA}, 0.05 \%$ bovine- $r$ globulin and $0.1 \%$ sodium azide, with $\mathrm{pH}$ adjusted to 8.0 . After incubation for a night at $4^{\circ} \mathrm{C}, 0.3 \mathrm{ml}$ of saturated ammonium sulfate solution was added to precipitate antibody-bound cortisol. After centrifugation, $0.5 \mathrm{ml}$ of the supernatant was pippeted into a counting vial. The radioactivity of the sample was counted together with $4 \mathrm{ml}$ of toluene scintilator. The amount of cortisol was determined by using a cubic regression equation fitted to standards $(0-400 \mathrm{pg})$ in each assay. The recovery through the whole procedure was $87 \%$. The intra- and interassay coefficients of variation were $9.8 \%$ and $12.9 \%$, respectively. The antiserum was prepared from one of four rabbits immunized against cortisol-21-BSA conjugate. Cross-reactivities of the antiserum were as follows: cortisol $100 \%$, corticosterone $121 \%$, cortisone $31 \%$, pregnenolone $8 \%$, deoxycorticosterone $10 \%$, testosterone $8 \%$, progesterone $9 \%, 17 \alpha-$ 
estradiol $6 \%, 17 \beta$-estradiol $6 \%$ and cholesterol non-detectable.

\section{Statistical analysis}

Since cortisol is secreted episodically, the absolute concentrations of plasma cortisol are not normally distributed. Their logarithms are, however, often so. Hence plasma cortisol concentrations were transformed to common logarithms and analysed by the least squares analysis of variance method using the LSML 76 program ${ }^{15)}$. The sources of variation considered were individual animals (random effect) and time in successive 2-hour periods (called time groups). The data before and after feeding were also analysed where individual animal and the time after feeding were considered source of variation. The effect of repeat (day) and the interaction between individual animal and the time were not statistically significant in both cases in prelim. inary analysis. Statistical comparisons among least squares means were carried out by Duncan's new multiple range test, regarding the effect of individual animal as a fixed effect.

\section{Results}

Plasma cortisol profiles of the three repeats in the four sheep are shown in Fig. 1A-D. It two cases, prominent peaks reaching $30 \mathrm{ng} / \mathrm{ml}$ and $29 \mathrm{ng} / \mathrm{ml}$ were observed (Fig. 1A, Repeat 2, 3). Since these values deviated greatly from the normal range in this study, it was considered that some unusual external stimuli had been given these cases. They were excluded from the data for statistical analysis.
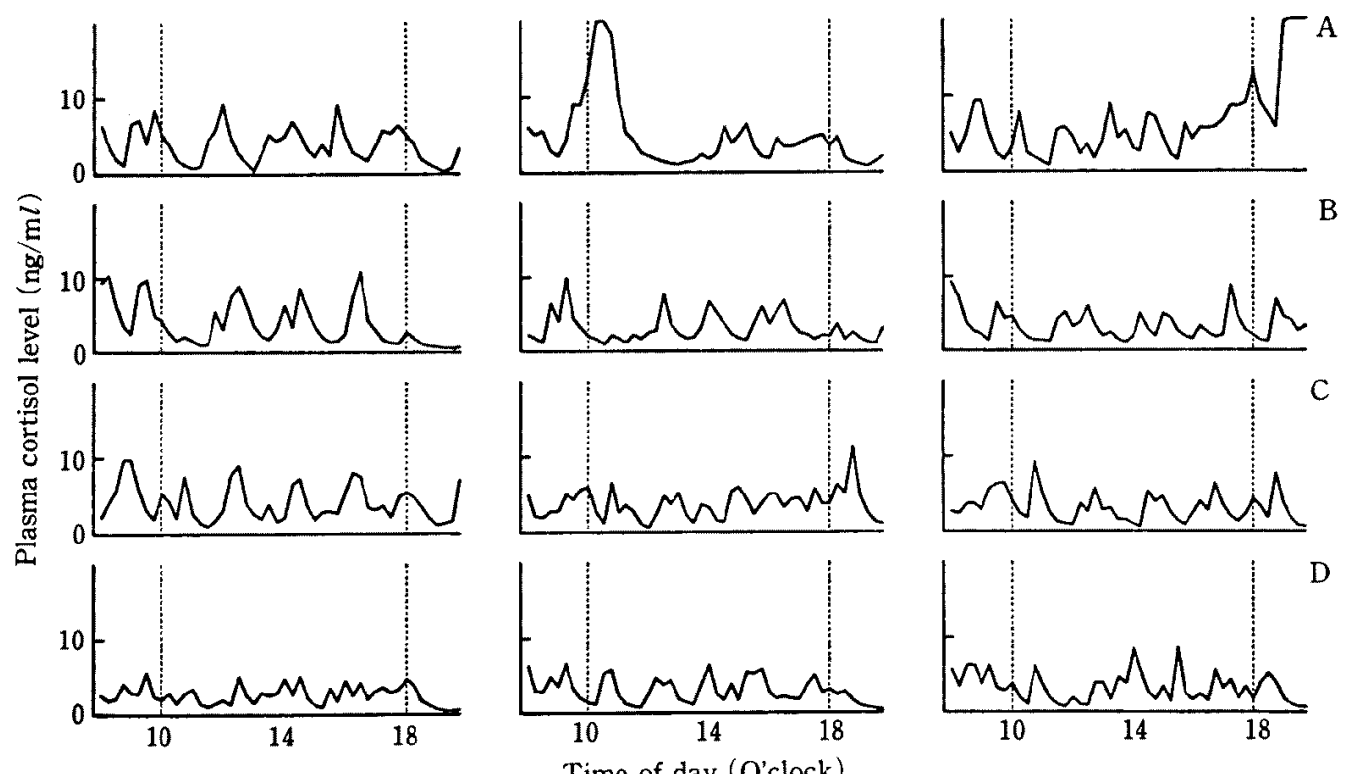

Fig. 1. Plasma cortisol profiles for 12 hours in 4 sheep at 3 repeat. A, B, C and D in rows denote individual animals, A: No. 24, B: No. 28, C: No. 31 and D: No. 88 . From left to right, each column of figures applies to repeat 1,2 and 3 , respectively. Time of feeding is shown by dashed line. 


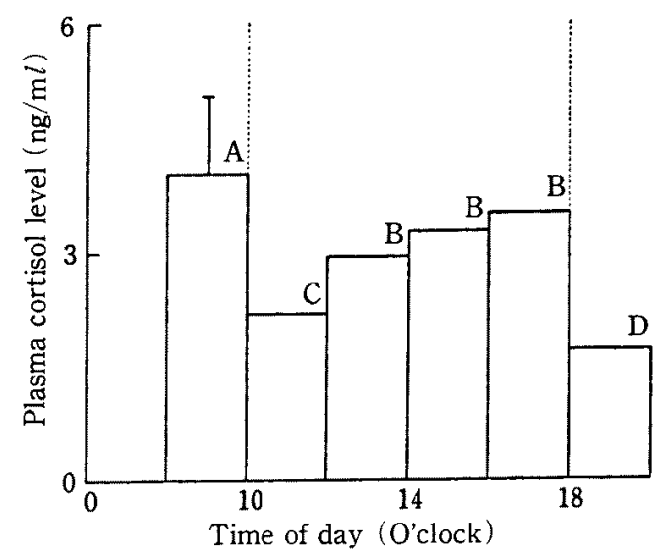

Fig. 2. Least squares means of plasma cortisol of the time grouped in successive 2-hour period. Antilogs of values are given in this figure. Time of feeding is shown by dashed line. The vertical line indicates standard errors of the least squares means. Means with different letters are significantly different from each other $(P<0.01)$.

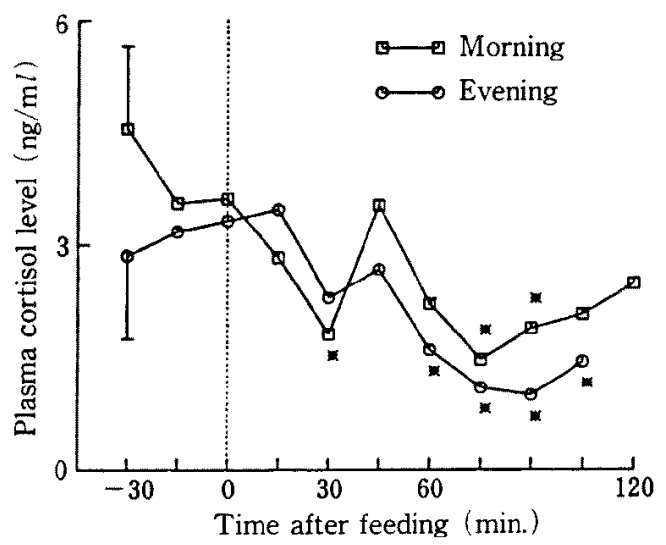

Fig. 3. Changes in average plasma cortisol levels before and after feeding. Antilogs of values are given in this figure. Time of feeding is shown by dashed line. The vertical line indicates standard errors of least squares means. Standard error is given only to the initial value, since the errors are identical in the method of least squares analysis of variance. Values with asterisk $\left(^{*}\right)$ are significantly different from each of the values at $0 \mathrm{~min}$.

Plasma cortisol level was significantly affected by the successive 2-hour periods (time groups) and individual animals $(P<0.01)$. The least squares means of time groups for 12 hours are shown in Fig. 2. The level of plasma cortisol before feeding in the morning (0800-1000) was significantly higher than that in any other time group $(\mathrm{P}<0.01)$. On the other hand, the level before evening feeding (1615-1800) was not significantly different from those of the preceding two time groups. The levels after 
both feedings in the morning and in the evening were significantly lower than those before the respective feedings $(\mathrm{P}<0.01)$.

The least squares means of plasma cortisol concentration in the samples taken at 15-minute intervals before and after feeding are shown in Fig. 3. Significantly low levels of plasma cortisol concentration were observed at 30,75 and 90 minutes after feeding, compared with that before feeding in the morning $(P<0.05)$. A similar trend was found in the evening feeding with the significant decrease during a period between 60 and 105 minutes after feeding $(P<0.05)$.

\section{Discussion}

A close relationship between circadian variations in the plasma corticosterone level and feeding has been shown in rats ${ }^{4-\theta)}$. The peak of circadian variations in the hormone level exists naturally at the transition period from day to night, when they begin to be active. The animals almost feed during their active period. The time for the peak to occur is shifted to just before feeding, when they are accustomed to newly scheduled feeding. This response is known as an anticipatory response to feeding, since it would appear from the peak that the time of feeding is anticipated. Thus, the time of the circadian peak level for the hormone appears to be determined by the feeding time.

The rise in plasma glucocorticoid level prior to feeding time may have some physiological significance. The activation of tyrosineaminotransferase in the liver ${ }^{1)}$ for subsequent absorption of amino acids and the potentiation of insulin secretion ${ }^{16)}$ have been reported to be roles of the rise of the hormone level prior to feeding. It seems also to possess preparative roles for various metabolic changes before and after feeding, and also for certain of the animals' activities.

In the present study using sheep, the pattern of the change in plasma cortisol level was very unclear in the raw data (Fig. 1, A-D), but some tendencies toward an increase before feeding and a decrease after feeding were suspected. These underlying tendencies were inspected by averaging these plasma cortisol concentrations over every 2-hour period. The level of plasma cortisol before feeding in the morning was higher than in any other time groups (Fig. 2). This result agrees with Holly et al. ${ }^{\text {9) }}$ who observed, in sheep, the levels of plasma cortisol before feeding at 1600 were by $30 \%$ higher than their daily means. The phase relationship between the rise of the hormone level and feeding in sheep is similar to that in rats ${ }^{4-6}$. Therefore the rise can be considered to be an anticipatory response to feeding.

On the other hand, we did not observe any significant rise before the second feeding at 1800 . According to a recent study by Honma et al. using rats ${ }^{17}$, the rise in the plasma corticosterone level was absent before the second feeding given at 6 hours after the first. The anticipatory response was observed only prior to the first feeding. The rats' anticipatory response is controlled by a circadian anticipatory system in the brain $^{6,18,19}$. Honma et al. postulated that a time interval of about 24 hours was measured by this system, and the measurement of the time was initiated only by the first feeding 
and not by the second. Therefore, the absence of the rise before the second feeding does not necessarily contradict the presence of an anticipatory response in sheep.

The least squares means of plasma cortisol level were lowered significantly after feeding (Fig. 2), and the decrease is confirmed in a more detailed figure (Fig. 3). The plasma cortisol levels dropped at 30 minutes after both the feedings in the morning and in the evening and thereafter the low values were maintained. The decrease in the plasma corticosterone level after feeding has also been observed in rats $^{20)}$ and chicks $^{21.22)}$, and it can be divided into two phases. The first phase may be caused by some neural stimuli related to feeding, for the hormone level dropped only upon presentation of food in both species ${ }^{20.22)}$. The initial drop is followed by a sustained low hormone level, if the animals are actually fed. The consumption of food or the metabolism of ingested food are responsible for the maintenance of the low values. The duration of the low plasma cortisol levels after feeding in sheep appears to be caused by a similar decreasing effect of food ingestion to that in these two species, although the nature of the initial drop is unclear.

In this study, we show the pattern of changes in the plasma cortisol levels associated with feeding in sheep. The changes seem to be similar to the findings obtained in rats ${ }^{4-\theta}$. It is assumed that the rise in the plasma cortisol level before feeding in the morning is an anticipatory response to feeding. This assumption, how ever, depends only on the phase relationship between the rise in the hormone level and feeding. To support this, other evidence using sheep is required.

\section{Acknowledgements}

The authors are grateful to Prof. K. Namikawa, Kyoto University and Dr. Y. ARIMA, Shimane Livestock Ex., St., for critical reading of this manuscript. We are also grateful to Mr. T. Higashimaki for cooperation in the establishment of a radioimmunoassay procedure and to the Radioisotope Center in Kyoto University for facilitating our radioimmunoassay.

\section{References}

1) Kato, H. and M. Saito, Biochim. Biophys. Acta, 627: 109-111, 1980.

2) Sulzman, F. M., C. A. Fuller and M. C. Moore-ede, Comp. Biochem. Physiol., 59A: 279-283. 1978.

3) Horseman, D. N. and C. F. Ehret, Amer. J. Physiol., 243: R373-378, 1982.

4) Krleger, D. T., Endocrinology, 95: 1195-1201. 1974.

5) Morimoto, Y., K. Arisue and Y. Yamamura, Neuroendocrinology, 23: 212-222. 1977.

6) Kato, H., M. Saito and M. Suda, Endocrinology, 106: 918-921. 1980.

7) Mcnatty, K. P., M. Cashmore and A. Young, J. Endocr., 54: 361-362. 1972.

8) Bassett, J. M., Aust. J. Biol. Sci., 27: 167-181. 1974.

9) Hozly, D. C., D. A. Beckmai and J. W. Evans, J. Endocr, 65: 147-148. 1975.

10) Barrelt, G. K. and K. R. Lapwood, Neuroendocrinology, 27: 216-227, 1978.

11) Fulkerson, W. J. and B. Y. TANG, J. Endocr., 81: 135-141. 1979.

12) Kennaway, D. J., J. M. Obst, E. A. Dunstan and H. G. Friesen, Endocrinology, 108: 639-646. 1981.

13) Lincoln, G. A., O. F. X. Almedia, H. Klandorf and R. A. Cunninghan, J. Endocr, 


\title{
Feeding Effect of Ovine Plasma Cortisol
}

92: $237-250.1982$.

14) Makino, T. and A. Kambegawa, Folia Endocrinol. Jpn., 49: 1297-1305. 1973. (in Japanese)

15) Harvey, W. R., User's guide for LSML76. Monogr., Ohio State University, Columbus, Ohio. 1977.

16) Saito, M. and H. Kato, Biomed. Res., 2: 285-290. 1981.

17) Honma, K., S. Honma and T. Hiroshige, Amer. J. Physiol, 246: R721-R726. 1984.

18) KRIEger, D. T., Endocrinology, 106: 649-654. 1980.

19) Honma, K., C. Goetz and J. Ashoff, Physiol. Behav., 30: 905-913. 1983.

20) HeYbach, J. P. and J. Vernikos-danellis, Neuroendocrinology, 28: 329-338. 1979.

21) Harvey, S. and H. Klandorf, J. Endocr., 98: 129-135. 1983.

22) Harvey, S., H. Klandorf and Y. Pinchasov, Neuroendocrinology, 37: 59-63, 1983.

ヒツジにおける給餌に伴う血浆中コルチゾール濃度の変動

\author{
村山真治・守屋和幸* ・佐々木義之 \\ 京都大学農学部, 京都市 606 \\ * 宮崎大学農学部, 宮崎市 880
}

\begin{abstract}
ヒツジに括ける血徆中ュルチゾール濃度の日内での変 動に対して，給期が関与するからかについて倹討した。 1 日 2 回の給慨時刻，拈よびその内容を一定にし，その 条件に惯らした 4 頭の去勢成熟七ツジ対し，15分間隔 の血液サンプリングを午前 8 時より12時間にわたり行な い，血洜中コルチソール濃度を剆定した。サンブリング は1週間ごとに 3 回綝返した。得られたデータに対し て，給解時刻を留意した 2 時間ごとの時間のグルーブを 要因上する最小自乗分散分析法により，統計処理を行な
\end{abstract}

った、その結果，この時間グループの要因は有意であっ た $(\mathrm{P}<0.01)$. 最小自乗平均值では，朝の給慨前のグル ープの值がもっとも大きいことが示された $(\mathrm{P}<0.01)$. また，朝夕の給慨值後のグルーブの值は，給期前のグル ープと比べて，各々有意に小さいことが認められた（P

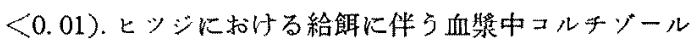
と濃度の变動は，ラットに扣いて認められているバター ンに類似しているものと推察される。

日畜会報，57（4)：317-323，1986 